\title{
ゆらぎで観た溶液科学
}

\section{Solution Chemistry Based on the Concept of Fluctuations}

\author{
西川恵子, 森田 剛
}

Keiko Nishikawa and Takeshi Morita

\begin{abstract}
Different intermolecular interactions in solutions produce various "mixing states", such as ideal mixing, formation of clusters with the same component or another component and phase separation. The structure of a solution has been expressed by the radial distribution function from the microscopic standpoint. As a complementation for solution chemistry, a mesoscopic viewpoint is necessary to clarify the mixing state of a solution, because the mixing state is expressed in terms of fluctuations of the molecular distribution which are actualized in the mesoscopic special scale. The theoretical concept on fluctuations for solutions was first presented by Bhatia and Thornton. We established experimental methodologies to elucidate structures of solutions with fluctuations. For various solutions and mixtures in supercritical states, we obtained their density fluctuations, concentration fluctuations, particle-number fluctuations of individual components, and the Kirkwood-Buff parameters. As two examples, we present the mixing states of acetonitrile aqueous solutions and the ones of an n-pentane-water mixture in the supercritical state.
\end{abstract}

Keywords: solution chemistry, mixing state, concentration fluctuation, particle-number fluctuation

\section{1. はじめに}

“ゆらぎ”は平均からのズレを表す概念である。空間的な 分子分布のズレ（静的ゆらぎ）や時間的变動（動的ゆらぎ） は，対象とする系の構造・物性を決め，その後の時間発展 の駆動力となる。宇宙の成り立ちから生命現象の理解に至 るまで，ゆらぎをキーワードとした研究が物理及び生命科 学の分野では盛んに進んでいる。しかし, 物質科学の分野 では，まだゆらぎに対す関心度は低いのではないだろうか。 本稿では, 物質科学においてゆらぎが顕在化する例の一つ として溶液の混ざり具合（“濃度ゆらき”という物理量で表 される) を取り上げる。

西川が“ゆらぎ”という物理量に興味を持ったのは，以 下の経緯による。東京大学理学研究科化学コースの博士課 程に入学早々 4 ケ月で中退し, 村田好正先生（当時, 学習 院大学教授）の助手として採用された。研究指導もして下 さるとのことで，3つの新しいテーマを提示された。そのう ちの一つが「エネルギー分散型液体用 $\mathrm{X}$ 線回折装置の製作 と解析方法の確立」であり, 規則構造を持たない複雑凝集 系との最初の出会いであった。複雑凝集系の構造は動径分 布関数で表現するのが一般的である。動径分布関数は, 実 験的には, X 線や中性子の散乱強度 $I(s)$ をフーリエ変換し て得られる。通常は, 散乱パラメータ $s$ (散乱ベクトルの絶 対值 $; s=4 \pi \sin \theta / \lambda ; 2 \theta$ : 散乱角, $\lambda: \mathrm{X}$ 線の波長）を掃引 するのに, 角度を掃引する角度分散法が一般的であるが, 白色 $\mathrm{X}$ 線（様々な波長すなわち様々なエネルギーの X 線が 混合）を使い一度に散乱データを得て, ディテクターにエ
ネルギー分析させる方法への転換であった。この装置開発 と並行して, 一成分液体の構造解析を進めていた。しかし, 次の節で述べるような動径分布関数法の限界をすぐに感じ た。

村田先生は表面科学がご専門であるが，様々な分野に興 味を持たれており，新しい液体の科学を作ろうとされてい た方々と研究グループを作られていた。そのメンバーには, 故藤山常毅先生（当時, 東京都立大その直後分子研), 茅幸 二先生 (当時慶応義塾大学), 細谷治夫先生 (お茶の水大 学), 片岡洋右先生 (当時京都大学) がいらした。この研究 グループの目的は, 液体や溶液を理解するのに（今では当 たり前の観点であるが), 液体中の分子を孤立分子として認 識するのではなく, 相互作用を取り込んで, 分子の集合体 として理解しようとすることであった。西川は, 村田先生 に連れられてこの研究会に何度か参加させていただいた。 この研究会の中心が藤山常毅先生で, 赤外吸収スペクトル の振動数シフトや幅から凝集系の相互作用を研究されてお られ，さらに可視光の Brillouin 散乱強度から二成分液体の 濃度ゆらぎを求める実験を開始されていた。動径分布関数 法での構造解析に限界を感じていた西川は，自然に「ゆら ぎ」に引かれていった。可視光の散乱からゆらぎの情報が 得られるのなら，X 線でも小角の散乱を観測すれば，ゆら ぎを求められるのではないかと漠然と考えていた。そして, 上記のエネルギー分散法の装置製作と解析法の確立 ${ }^{1}$ (10 年 近くを要した!!）の後, 小角 X 線散乱装置の製作に取りか かった。「ゆらぎ」との出会いは藤山先生の影響であるし， 
装置は自分で作るのだということをご指導して下さったの は村田先生である。

森田は, 西川が横浜国立大学へ赴任してから, 当初は大 学院生として複雑凝集系の研究に関わることになる。現在 は研究室スタッフとして様々な系のゆらぎの研究に携わっ ている。特に装置製作を得意としており, 解析例として本 稿の最後に述べる超臨界状態の $n$-pentane - 水系の実験のた

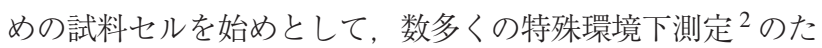
めの装置の設計・製作を手がけた。このように，オリジナ ルな装置の製作を含めた我々の実験手法が, “only one”の研 究を支えていると自負している。

\section{2. 液体・溶液の構造表現}

液体や溶液の構造表現としては，動径分布関数が一般的 である3。動径分布関数は，ある粒子を中心にしてほかの粒 子がどのように分布しているのかを表したものである。こ こであえて “粒子”と記したのは取り扱い方法や実験方法 によって“粒子”が異なってくるからである。例えば，理 論的取り扱いでは“粒子”は分子であることが多い。しか し通常の回折実験では, “粒子”は個々の散乱点である原子 である。“粒子”が原子であるか, 分子であるかの違いは, 分子性液体のような多原子分子液体の場合, 特に意識する 必要がある1。

液体や溶液中の任意の原子に乗って時間を止めた状態で 他の原子を見渡すと, その周りに分子の形や相互作用を反 映した三次元的異方性をもった構造が存在する。そして, この中心の原子は液体あるいは溶液中のどの原子を選んで もよいわけである。また，運動により分子は時々刻々その 位置を変えている。我々の観測にかかる量は, 位置・時間 について平均化した量であり, 三次元的微視的構造も, こ のような平均化のもとでは一次元の情報となってしまう。 一次元の情報から三次元の構造を知ることは原則的に不可 能である。また, 回折実験から得られる二体分布関数 $g_{\mathrm{ij}}(r)$ $\left(4 \pi r^{2} g_{\mathrm{ij}}(r)\right.$ が動径分布関数) は, 系内のあらゆる原子の重ね 焼きであり (ここでの分布関数は原子の分布関数), それか ら解きほぐして対象とする試料の微視的構造を云々するこ とは難しい。液体や溶液構造の研究において, このように 動径分布関数による方法は構造について最も有用な情報を 与えるものであるが, 成分元素が多くなるとその解釈には 大きな困難が伴う。

今, A， B という二種類の液体を混ぜた溶液を考えよう。 $\mathrm{A}, \mathrm{B}$ それぞれの分子が完全ランダムに混ざり合う理想的混 合, 同種あるいは異種分子同士が会合する会合混合, 臨界 点を経ての相分離等々様々な混ざり方が考えられる。こう した混ざり方の違いを動径分布関数だけから明らかにする のは難しい。それは先にあげた限界とともに, 動径分布関 数ではある原子を中心としてせいぜい $10 \AA$ 程度の近接を見 ているのにすぎないからである。混合状態を云々するには，
数十〜数百 §にわたる空間を観測しなければ判断できない ことが多い。いわば動径分布関数法は，観測する“眼”を 対象試料に非常に近づけて近視眼的に細かく観測している ことに相当する。“眼”をだんだん離し，一つ一つの原子や 分子はぼやけるが, 全体的にとらえ混合状態を定量的に表 現することができないだろうか？

混合状態の定量的表現方法として“ゆらぎ”の概念が有 効である。その一つは, ある体積 $\Delta V$ 中の分子数の平均個数 からのズレ $\Delta N$, 分子の平均濃度からのズレ $\Delta c$ を使った密 度ゆらぎと濃度ゆらぎによる表現である。（密度ゆらぎと濃 度ゆらぎの正確な定義は, 後に述べる。）いま一つは, 二体 分布関数 $g_{\mathrm{ij}}(r)(\mathrm{i}, \mathrm{j}$ は A または B, すなわちこの分布関数 は分子の部分二体分布関数) を使った次のような表現であ る。

$$
G_{\mathrm{ij}}=\int\left(g_{\mathrm{ij}}(r)-1\right) d V
$$

$G_{\mathrm{ij}}$ は, Kirkwood-Buff のパラメータと呼ばれる量である ${ }^{4} 。$ $g_{\mathrm{ij}}(r)$ は, i と j の分子間距離 $r$ の増大とともに 1 に漸近的 に変化する関数であり， $G_{\mathrm{ij}}$ はやはり平均からのズレを表し ているゆらぎの一表現である。Kirkwood と Buff ${ }^{4}$ および Ben-Naim ${ }^{5}$ は $G_{\mathrm{ij}}$ を用いて様々な熱力学量を表すことが出来 ることを示した。Kirkwood-Buff のパラメータおよび密度ゆ らぎや濃度ゆらぎは, 原子間距離等のミクロな構造の情報 と, 熱力学・統計力学のマクロな物性值をつなぐ物理量と 言える。また, Kirkwood-Buff のパラメータとゆらぎは, 微 分や積分を含まない解析的な式で結びつけられており（式 (21) および(22)参照), 同じ階層性に属する物理量である6。

Kirkwood-Buff のパラメータあるいは密度ゆらぎや濃度ゆ らぎという物理量を待つまでもなく, 二体分布関数 $g_{\mathrm{ij}}(\mathrm{i}$, $\mathrm{j}$ は分子）そのものが, 既にミクロな量とマクロな量を直接 つなぐ物理量だと言われるかもしれない。確かに液体や溶 液の二体分布関数 $g_{\mathrm{ij}}(r)$ と分子に働くポテンシャルエネル ギー $\Phi(r)$ がわかれば, この二つの量を使って溶液のすべて の熱力学量は計算できる。実際, 液体論の教科書には, $g_{\mathrm{ij}}(r)$ や $\Phi(r)$ と熱力学的諸量の関係式が列挙されている ${ }^{3}$ 。 しかし，ここで実験的には問題が二つある。一つは，二体 分布関数を求める実験は回折実験が一般的であるが, それ から求められるのは, 原子に対する分布関数 $g_{\mathrm{ij}}(r)(\mathrm{i}, \mathrm{j}$ は 原子）であり，しかも，原子の散乱能の重みを持ったすべ ての重ね合わせであることである。単原子分子液体でない かぎり, 熱力学的諸量の計算に必要な分子の分布関数は, 近似計算によるしかない。第 2 に問題なのは, 動径分布関 数と熱力学量をつなぐ式は, すべて二体分布関数を含む全 空間にわたる積分で表されていることである。単原子分子 液体などで, 真の意味の動径分布関数がわかったとしても, 全範囲にわたって積分して有意な結果を得るほど精度良く 測定することは困難である。このように, 確かに動径分布 関数と熱力学量は式の上で結びついているが, それは理論 
上のことで現実の系に適用して扱うことは不可能である。 近似もなく実験的に直接得られる量となると, KirkwoodBuff のパラメータあるいは密度ゆらぎや濃度ゆらぎとなる。

密度ゆらぎや濃度ゆらぎあるいは Kirkwood-Buff のパラ メータは，X 線の小角散乱実験において散乱強度を $s \rightarrow 0$ に外挿した值 $I(0)$ と, 熱力学量 (等温圧縮率, 部分モル体 積）を組み合わせることによって，直接しかも各成分が分 離された形 $\left(G_{\mathrm{ij}}\right.$ であれば, $\left.G_{\mathrm{AA}}, G_{\mathrm{BB}}, G_{\mathrm{AB}}\right)$ で求められる。

この節では, 実験で求める二体分布関数 $g_{\mathrm{ij}}(r)$ の限界につ いて強調しすぎたきらいがある。上記したような限界を越 える様々な研究手法の開発が進んでいる。例えば, 計算機 シミュレーションとの併用がその一つである。また, 同位 体置換した試料の中性子散乱実験や吸収端近傍の X 線を用 いて, $g_{\mathrm{ij}}(r)$ を各成分 $g_{\mathrm{AA}}(r), g_{\mathrm{BB}}(r), g_{\mathrm{AB}}(r)$ の部分二体分布 関数に分ける方法等である。これらの手法で, 意義深い データが多数報告されていることを言及しておく。我々の ゆらぎをプローブとした手法は, ミクロスケールの詳細な 情報を得る替わりに，メゾスケールの “眼” で溶液構造を 理解しようとするものである。

\section{3. 密度ゆらぎ・濃度ゆらぎと回折強度の関係}

これから, 小角散乱強度とゆらぎの関係を定式化してい くが，X 線小角散乱を想定して述べる。中性子散乱の場合 は, これからの式の X 線の散乱振幅を中性子のそれに置き 変えればよい。ゆらぎと散乱強度を直接結びつけて定式化 したのは Bhatia と Thorntonである 7 。通常の回折学におい ては, 散乱強度は各原子を散乱点として, その位置 $\boldsymbol{r}$ また は $r$ をあらわに含んだ形で表現するが，彼らは，体積 $\mathrm{d} V$ 中の密度ゆらぎと濃度ゆらぎに関係する量を新たに定義し て散乱の一般式を導いた。成分が A と B からなる混合液 体を考える。彼らは, 実空間の点 $\boldsymbol{r}$ における分子（A，Bに 区別なく）の数密度の平均数密度からのズレを $\Delta n(\boldsymbol{r})$, また 濃度の平均濃度からのズレを $\Delta c(\boldsymbol{r})$ として, これらのフーリ 工変換すなわちズレの逆空間表示を $\mathfrak{N}(s), \mathfrak{C}(s)$ とした。

$$
\mathcal{N}(s)=\int \exp (i s \boldsymbol{r}) \Delta n(\boldsymbol{r}) d \boldsymbol{r}
$$

$$
\mathcal{C}(s)=\int \exp (i s \boldsymbol{r}) \Delta c(\boldsymbol{r}) d \boldsymbol{r}
$$

系全体からの散乱強度を $I(s)$ とすると,

$$
\begin{aligned}
I(s) / \bar{N}= & \overline{F^{2}} S_{N N}(s)+\left(F_{\mathrm{A}}-F_{\mathrm{B}}\right)^{2} S_{C C}(s) \\
& +2 \bar{F}\left(F_{\mathrm{A}}-F_{\mathrm{B}}\right) S_{N C}(s)
\end{aligned}
$$

と表される。ここに $F_{\mathrm{i}}(\mathrm{i}=\mathrm{A}$ あるいは $\mathrm{B})$ は $\mathrm{i}$ 分子の散乱 振幅であり, 平均值 $\bar{F}$ は

$$
\bar{F}=c_{\mathrm{A}} F_{\mathrm{A}}+c_{\mathrm{B}} F_{\mathrm{B}}
$$

である。 $c_{\mathrm{i}}$ は $\mathrm{i}$ 分子のモル分率である。また $S_{N N}(s), S_{C C}(s)$, $S_{N C}(s)$ は，(2)，（3）式の密度及び濃度のズレの逆空間表示 $\mathcal{N}(s), \bigodot(s)$ を用いて，以下のように表される。

$$
\begin{aligned}
& S_{N N}(s)=<\mathcal{N}(s) * \mathcal{N}(s)>\bar{N} \\
& S_{C C}(s)=\bar{N}<\mathcal{C}(s) * \mathcal{C}(s)> \\
& S_{N C}(s)=\operatorname{Re}<\mathcal{N}(s) * \mathcal{C}(s)>
\end{aligned}
$$

<>あるいは上付きバーは平均值を，は複素共役を示す。 (4)式は，Van Hoveによって提案された dynamical structure factor ${ }^{8}$ を用いて導かれるが, その導出方法はかなり難解で ある。詳細は論文 ${ }^{7}$ を参照願いたい。

(4)式だけでは十分な実用性はない。しかしながら， $s \rightarrow$ 0 の極限值において，(4)式は重要な意味をもってくる。 $s \rightarrow 0$ の極限において $(6) \sim(8)$ の $S_{N N}(0), S_{C C}(0), S_{N C}(0)$ は ゆらぎそのものと結びつき，以下のようになる。

$$
\begin{aligned}
& S_{N N}(0)=<(\Delta N)^{2}>/ \bar{N} \\
& S_{C C}(0)=\bar{N}<(\Delta c)^{2}> \\
& S_{N C}(0)=<(\Delta N)(\Delta c)>
\end{aligned}
$$

(6’)，（7’)がそれぞれ密度ゆらぎ，濃度ゆらぎである。(8') は密度ゆらぎと濃度ゆらぎの相関を表す。

密度ゆらぎと濃度ゆらぎのイメージを Figure 1 で示す。 Figure 1(a) は，粒子（分子やイオンまとめて粒子と表現す る）が乱雑に分布している状態の一瞬を捉えたものである (具体的には超臨界状態における分子分布)。このように乱 れた系では，その中に規則性や平均構造を見出そうとする (a)

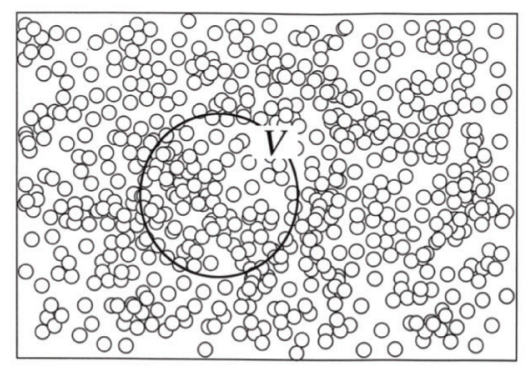

(b)

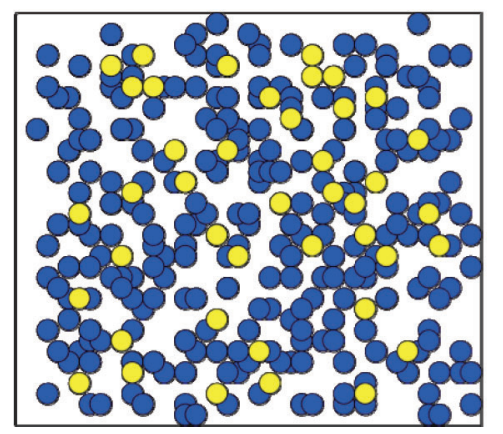

(c)

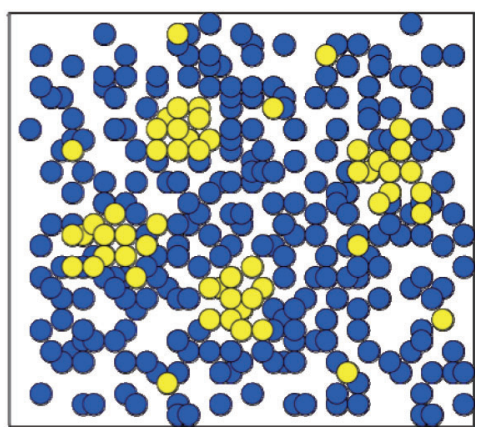

Figure 1. Density fluctuation and concentration fluctuation. (a) Snapshot of inhomogeneous distribution of molecules. (b), (c) Snapshots of distribution of two types of molecule. 
ことにはあまり意味は無く，乱れを乱れとして定量的に表 現することが本質的であると考えられる。系の中に体積 $V$ の空間を考え，その中に入る粒子数を $N$ としたときの空間 的粒子数のゆらぎは, $\left.<(\Delta N)^{2}\right\rangle=<(N-\bar{N})^{2}>$ である。 $<(\Delta N)^{2}>$ は, 注目する体積 $V$ すなわち $\bar{N}$ の大きさに依存す る。これを示強变数にするために $\bar{N}$ で割り, $<(\Delta N)^{2}>/ \bar{N}$ を密度ゆらぎと定義する。Figure 1 (b) と (c)に2 種類の粒子 が混じり合った状態を模式的に描いた。（b）は黄色の粒子と 青の粒子がランダムに混じり合った状態であり, (c)は黄色 の粒子がクラスターを形成している場合である。(a) と同様 に, 体積 $V$ の領域を考えると, その中の濃度のゆらぎは $\left.<(\Delta c)^{2}\right\rangle=\left\langle(c-\bar{c})^{2}\right\rangle$ と成る。この量を示強変数化するた めに, 今度は $\bar{N}$ を掛け, $\bar{N}<(\Delta c)^{2}>$ を濃度ゆらぎと定義す る。Figure 1(b) および $(c)$ は，それぞれ濃度ゆらぎの小さな 系および大きな系である。

$<(\Delta N)^{2}>I \bar{N}$ 等の表示はわずらわしいので, 密度ゆらぎ, 濃度ゆらぎおよびその相関をそれぞれ $S_{N N}(0), S_{C C}(0)$, $S_{N C}(0)$ で表すことにする。(4)式において $s \rightarrow 0$ とした式は,

$$
\begin{aligned}
I(0) / \bar{N}= & \bar{Z}^{2} S_{N N}(0)+\left(Z_{\mathrm{A}}-Z_{\mathrm{B}}\right)^{2} S_{C C}(0) \\
& +2 \bar{Z}\left(Z_{\mathrm{A}}-Z_{\mathrm{B}}\right) S_{N C}(0)
\end{aligned}
$$

ここでは X 線回折実験を想定して, 分子の散乱振幅 $F_{\mathrm{i}}(s)$ を 分子内の総電子数 $Z_{\mathrm{i}}$ に置き換えた。 $s \rightarrow 0$ においては, 位 相項が 0 となり， $F(0)$ は方向に依存しない $Z_{\mathrm{i}}$ となる。 また

$$
\bar{Z}=c_{\mathrm{A}} Z_{\mathrm{A}}+c_{\mathrm{B}} Z_{\mathrm{B}}
$$

である。(4)式は一般式であり，その導出は前述したように かなり難解である。ゆらぎを議論するには (4')式が重要で あり， $s \rightarrow 0$ とした $\left(4^{\prime}\right)$ 式は，比較的簡単に導かれる9。

さて, (4') 式は, 密度ゆらぎ, 濃度ゆらぎ, そしてそれ らの相関と三つの求めたい式を同時に含む。これら三つの 項を分離するには，どうしたらよいであろうか？一つの答 は，散乱振幅の異なる線源あるいは試料を用いて，三種類 の散乱実験を行うことである。(4')式において，各々のゆ らぎの前にかかる係数が異なる三つの等式ができ, 連立方 程式を解く要領で各々のゆらぎは分離できる。この手法は 二成分からなるアモルファス合金や融体の部分二体分布関 数 $g_{\mathrm{ij}}(r)$ (i， j は原子）を $g_{\mathrm{AA}}, g_{\mathrm{BB}}, g_{\mathrm{AB}}$ に分けるのによく 使われる ${ }^{10}$ 。散乱実験の組み合わせとしては，X 線散乱, 中性子散乱, 吸収端近傍での波長を用いることにより X 線 散乱振幅を変化させる散乱実験, 試料中の同位体の組成比 を変えての中性子散乱実験などが考えられる。すなわち,

（4'）式の $Z_{\mathrm{i}}(\mathrm{i}=\mathrm{A}$ または B ）を変えた 3 つの方程式をた てることに相当する。しかし，上記に述べたのは，理論上 での可能性であって, 連立させて各項を分離するほど精度 よく三つの散乱実験を行うのは難しい。ゆらぎは, 熱力学 的マクロな物理量に結びつくのでここでは, 熱力学量を積
極的に取り入れることを試みてみる。ゆらぎの各項を熱力 学量で表してみると ${ }^{7}$

$$
\begin{aligned}
& S_{C C}(0)=\bar{N} k_{\mathrm{B}} T /\left[\frac{\partial^{2} G}{\partial c^{2}}\right]_{T, p, N} \\
& S_{N N}(0)=(\bar{N} / V) k_{\mathrm{B}} T \kappa_{T}+\delta^{2} S_{C C}(0) \\
& S_{N C}(0)=-\delta S_{C C}(0)
\end{aligned}
$$

となる。ここに， $k_{\mathrm{B}}$ は Boltzmann 定数， $G$ は Gibbs エネル ギー, $T$ は絶対温度， $\kappa_{T}$ は等温圧縮率である。等温圧縮率 は以下の式で与えられる。

$$
\kappa_{T}=-\frac{1}{V}\left(\frac{\partial V}{\partial p}\right)_{T}
$$

また, $\delta$ は, $\mathrm{A}$ 分子と $\mathrm{B}$ 分子の大きさの違いを補正する項 で,

$$
\delta=\left(v_{\mathrm{A}}-v_{\mathrm{B}}\right) \bar{N} / V
$$

で与えられる。 $v_{\mathrm{A}}$ は $\mathrm{A}$ 分子の部分モル体積で, 濃度の関数 である。濃度 $c$ の溶液に無限少量の $\mathrm{A}$ を加えた場合, $\mathrm{A}$ 分 子 1 個が溶液中で占める体積である。この量は, 細かく濃 度を変えて各濃度で密度測定をすることによって, それほ ど困難無くまた精度良く求めることが出来る。これに対し て $\kappa_{T}$ を決める実験はたいへんで, 多くの溶液系で決定され ているわけではない。(10), (11)を(4')に代入すると,

$$
\begin{aligned}
I(0) / \bar{N}= & \overline{Z^{2}}(\bar{N} / V) k_{\mathrm{B}} T \kappa_{T} \\
& +\left\{\bar{Z} \delta-\left(Z_{\mathrm{A}}-Z_{\mathrm{B}}\right)\right\}^{2} S_{C C}(0)
\end{aligned}
$$

となる。すなわち， X 線小角散乱実験を行い強度デー夕を $s \rightarrow 0$ に外挿した值と， $\kappa_{T}$ および各成分の部分モル体積よ り, 濃度ゆらぎが求められる。さらに，(10), (11)より溶 液の密度ゆらぎ, 密度ゆらぎと濃度ゆらぎの相関も求めら れる。

$$
\begin{aligned}
& \text { 一成分の場合は濃度ゆらぎが } 0 \text { となり，(4') と（10)により } \\
& \begin{aligned}
I(0) / \bar{N} & =Z^{2}(\bar{N} / V) k_{\mathrm{B}} T \kappa_{T} \\
& =Z^{2} S_{N N}(0)
\end{aligned}
\end{aligned}
$$

となり, 密度ゆらぎが $s=0$ での小角 $\mathrm{X}$ 線散乱強度や等温 圧縮率 $\kappa_{T}$ と比例関係にあることがわかる。この関係式は, 統計力学でよく知られた関係である。

(9)〜（11）式を用いて, 熱力学的測定だけからゆらぎすべ てが求められることになる。ならば, 回折実験は必要ない のであろうか? 熱力学的に濃度ゆらぎを求めるためには, Gibbs エネルギーの測定が必要である。しかも, この量の濃 度に対する二次の微分を求めなければならないので, 細か く濃度を変え精度よくGibbs エネルギーを測定しなければ ならない。熱力学的測定から直接濃度ゆらぎを議論した数 少ない例は，一価アルコールの水溶液系 ${ }^{11}$ である。濃度ゆ 
らぎが大きい系には小角 $\mathrm{X}$ 線散乱法が，濃度ゆらぎが小さ い系では Gibbs エネルギー測定が，精度良い結果を与える。

\section{Kirkwood-Buff のパラメータ}

式(1)で示される Kirkwood-Buff のパラメータの溶液化学 における重要性を指摘したのは，Ben-Naim である5。彼は， 二成分液体において, その溶液の三種類の熱力学量 $\left(\partial^{2} G / \partial c^{2}, v_{\mathrm{i}}, \kappa_{T}\right)$ から Kirkwood-Buff のパラメー夕を求 める方法を示し, エチルアルコール水溶液における混合状 態を議論した。Ben-Naim の示した式は

$$
\begin{aligned}
& G_{\mathrm{ij}}=k_{\mathrm{B}} T \kappa_{T}-\left(v_{\mathrm{i}} / v_{\mathrm{j}}\right) / D v \quad(\mathrm{i} \neq \mathrm{j}) \\
& G_{\mathrm{ii}}=G_{\mathrm{ij}}+\left(v_{\mathrm{i}} / D-v\right) / c_{i} \\
& D=c\left(\frac{\partial^{2} G}{\partial^{2} c^{2}}\right)_{T, p, N} / k_{\mathrm{B}} T
\end{aligned}
$$

である。 $G_{\mathrm{ij}}$ は(1) 式で示した Kirkwood のパラメータである。 (1) 式で示すように，二体分布関数の収束值（すなわち “1”）からのズレの全空間にわたる積分值である。2 成分系 では, $G_{\mathrm{AA}}, G_{\mathrm{BB}}, G_{\mathrm{AB}}$ の 3 つ項が出てくる。(18)式の $G$ は Gibbs エネルギーである。 $v$ は $V_{\mathrm{M}} / N_{\mathrm{A}}$ である（ $V_{\mathrm{M}}$ : 溶 液 $1 \mathrm{mo} 1$ あたりの体積, $N_{\mathrm{A}}$ : アボガドロ数)。Ben-Naim 以後, いくつかの低分子性溶液で, 上記三つの熱力学量から求め た Kirkwood-Buff のパラメータが発表されている12,13。

Gibbs エネルギー項の替わりに $s=0$ におけるX 線散乱 強度 $I(0)$ の測定值を使い Kirkwood-Buff のパラメータをゆ らぎと結び付けることができる ${ }^{6}$ 。二体分布関数 $g_{\mathrm{ij}}(r)$ を用 いて散乱強度式を表すと

$$
\begin{aligned}
I(s)= & N_{\mathrm{A}} F_{\mathrm{A}}(s)^{2}+N_{\mathrm{B}} F_{\mathrm{B}}(s)^{2} \\
& +\left(N_{\mathrm{A}}^{2} F_{\mathrm{A}}(s)^{2} / V\right) \int\left(g_{\mathrm{AA}}-1\right)\{\sin (s r) / s r\} d \mathbf{r} \\
& +\left(N_{\mathrm{B}}^{2} F_{\mathrm{B}}(s)^{2} / V\right) \int\left(g_{\mathrm{BB}}-1\right)\{\sin (s r) / s r\} d \mathbf{r} \\
& +\left(2 N_{\mathrm{A}} N_{\mathrm{B}} F_{\mathrm{A}}(s) F_{\mathrm{B}}(s) / V\right) \int\left(g_{\mathrm{AB}}-1\right)\{\sin (s r) / s r\} d \mathbf{r}
\end{aligned}
$$

となる。 $s \rightarrow 0$ とした極限值を $\bar{N}$ で割ると,

$$
\begin{aligned}
I(0) / \bar{N}= & c_{\mathrm{A}} Z_{\mathrm{A}}{ }^{2}+c_{\mathrm{B}} Z_{\mathrm{B}}^{2} \\
& +\left(Z_{\mathrm{A}}{ }^{2} n c_{\mathrm{A}}{ }^{2}\right) G_{\mathrm{AA}} \\
& +\left(Z_{\mathrm{B}}{ }^{2} n c_{\mathrm{B}}{ }^{2}\right) G_{\mathrm{BB}} \\
& +\left(2 Z_{\mathrm{A}} Z_{\mathrm{B}} n c_{\mathrm{A}} c_{\mathrm{B}}\right) G_{\mathrm{AB}}
\end{aligned}
$$

となる。これと $\left(4^{\prime}\right)$ 式の $Z_{\mathrm{A}}, Z_{\mathrm{B}}$ の係数を比較することにより

$$
\begin{aligned}
& S_{N N}(0)=c_{\mathrm{A}}{ }^{2} n G_{\mathrm{AA}}+c_{\mathrm{B}}{ }^{2} n G_{\mathrm{BB}}+2 c_{\mathrm{A}} c_{\mathrm{B}} n G_{\mathrm{AB}}+1 \\
& S_{C C}(0)=c_{\mathrm{A}} c_{\mathrm{B}}\left[1+n c_{\mathrm{A}} c_{\mathrm{B}}\left(G_{\mathrm{AA}}+G_{\mathrm{BB}}-2 G_{\mathrm{AB}}\right)\right] \\
& S_{N C}(0)=c_{\mathrm{A}} c_{\mathrm{B}} n\left[c_{A}\left(G_{\mathrm{AA}}-G_{\mathrm{AB}}\right)-c_{\mathrm{B}}\left(G_{\mathrm{BB}}-G_{\mathrm{AB}}\right)\right]
\end{aligned}
$$

逆に

$$
\begin{aligned}
G_{A A} & =\left[S_{N N}(0)+2 S_{N C}(0) / c_{\mathrm{A}}+S_{C C}(0) / c_{\mathrm{A}}{ }^{2}-1 / c_{\mathrm{A}}\right] / n \\
G_{\mathrm{BB}} & =\left[S_{N N}(0)-2 S_{N C}(0) / c_{\mathrm{B}}+S_{C C}(0) / c_{\mathrm{B}}{ }^{2}-1 / c_{\mathrm{B}}\right] / n \quad(22) \\
G_{\mathrm{AB}} & =\left[S_{N N}(0)+\left(c_{\mathrm{B}}-c_{\mathrm{A}}\right) S_{N C}(0) / c_{\mathrm{A}} c_{\mathrm{B}}-S_{C C}(0) / c_{\mathrm{A}} c_{\mathrm{B}}\right] / n
\end{aligned}
$$

である。ただし $n=\bar{N} / V$ (数密度) である。すなわち, ゆ らぎの各項を求めるのと同様に, 小角散乱実験から $I(0)$ を 求め, 等温圧縮率 $\kappa_{T}$ および部分モル体積 $v_{\mathrm{i}}$ を組み合わせ ることにより, Kirkwood-Buff のパラメータ $G_{\mathrm{ij}}$ の三つの項 を分離して求めることができる。

前述のようにKirkwood-Buff のパラメータを用いて様々 な熱力学量を表すことができる。ここでは, ゆらぎの立場 で Kirkwood-Buff のパラメータを物理的に意味付けてみる ${ }^{6}$ 。 $G_{\mathrm{ij}}$ に $\mathrm{i}$ 成分の数密度 $n_{\mathrm{i}}$ を乗ずると,

$$
\begin{array}{ll}
\mathrm{i}=\mathrm{j} \text { の場合 } & n_{\mathrm{i}} G_{\mathrm{ii}}=<\left(\Delta N_{\mathrm{i}}\right)^{2}>/ \bar{N}-1 \\
\mathrm{i} \neq \mathrm{j} \text { の場合 } & n_{\mathrm{i}} G_{\mathrm{ij}}=<\left(\Delta N_{\mathrm{i}} \Delta N_{\mathrm{j}}\right)>/ \overline{N_{\mathrm{j}}}
\end{array}
$$

となり, $\mathrm{i}=\mathrm{j}$ の場合 $\left(n_{\mathrm{i}} G_{\mathrm{ii}}+1\right)$ が $\mathrm{i}$ 成分の密度ゆらぎを, $\mathrm{i} \neq \mathrm{j}$ の場合 $n_{\mathrm{i}} G_{\mathrm{ij}}$ が $\mathrm{i}$ 成分と $\mathrm{j}$ 成分の密度ゆらぎの交差項を 示している。(6') および(10)で定義される密度ゆらぎは, 粒子の種類を区別しない全粒子数の密度ゆらぎである。

ゆらぎおよび Kirkwood-Buff のパラメータを求めるため の X 線小角散乱実験については，すでに実験書にまとめた ので ${ }^{14}$, そちらを参照願いたい。

\section{5. 部分構造の空間的広がり}

ゆらぎや Kirkwood-Buff のパラメー夕を求めるには，熱 力学的測定, 小角散乱実験の二つを示したが, これ以外に も光散乱データ (Rayleigh-Brillouin 散乱) を用いる方法 ${ }^{15}$ もある。熱力学量だけから求めた值は, マクロなスケール でのゆらぎである。光散乱では, 可視光数千 ^のプローブ でレーザ光の coherent length で定義される $V$ 内を観測して いるものと思われる。X 線では $1 \AA$ 程度の尺度で, $\mathrm{X}$ 線の coherent length ( $10^{4} \AA$ 程度か?) で定義される体積領域のゆ らぎを観測していると思われる。これら三つの方法で求め た值を比較してみるのも興味深い。しかし，残念なことに， 比較できるほど十分な数のデー夕は蓄積されていない。ま た，十分な精度で，ゆらぎや Kirkwood-Buff のパラメータ を求めることはむずかしい。そのような中で光散乱 ${ }^{16}$ と X 線小角散乱 17 で濃度ゆらぎを測定した tert-ブチルアルコー ル水溶液と, 熱力学量のみ 5 と X 線小角散乱 ${ }^{18}$ から Kirkwood-Buff のパラメータを決めたエチルアルコール水溶 液が比較の例となりうる。これらのデータでは, 誤差の範 囲内で一致しているように思える。

次に, 小角散乱実験でさらに加えられる情報について示 めそう。成分 $\mathrm{A}, \mathrm{B}$ が完全ランダムに混ざり合い，かつそ れぞれの分子の大きさの違いが無視できる場合, 濃度ゆら ぎは，簡単に計算でき $c_{\mathrm{A}} c_{\mathrm{B}}=c(1-c)$ となる。濃度ゆらぎ がこの值からずれている場合, 溶液中には何らかの部分構 造ができていることが考えられる（例えばクラスターの存 在）。こうした部分構造を調べるには，広角散乱実験により 動径分布関数を求めるのが常道となる。アセトニトリル (AN) 水溶液の広角散乱実験の結果を簡単に紹介する。 
$\mathrm{AN}$ 水溶液は, モル分率 $(c) 0.38,272 \mathrm{~K}$ で上部臨界点をも つ相分離する系である。臨界点近傍とそれ以外では混合状 態は大きく変わっていると思われるが, 動径分布関数には 何の変化も見いだされなかった。ANの場合は, 近接分子間 の変化を伴わずクラスターの大きさが変化しているものと 思われる。このような場合，比較的小さな領域を近視眼的 に観測していると，変化の様子が捉えられないこともある。

どの分子とどの分子が何 ̊くらいの距離で構造を作って いるかというようなクラスターの内部構造の詳細は得られ ないにしても, この部分構造をひと塊と考え, クラスター の大きさが何 $\AA$ 程度かというような議論はできないだろう か? 勿論ここでのクラスターは, 空間的・時間的に平均化 されたクラスターである。そして, その平均像は, それを とる頻度が最も高いという意味で, 溶液内の分子間相互作 用を直接反映したものであり，溶液の混合状態を端的に表 したものと言えよう。

部分構造の大きさの目安を与えるものとして, 小角散乱 実験から求まる相関距離がある。 $\mathrm{X}$ 線小角散乱の場合, 電 子密度の不均一さが観測にかかるが, この不均一の空間的 大きさをクラスターの大きさとしょうとするものである。 $X$ 線小角散乱曲線の形状から電子密度不均一領域の大きさ を見積もることができる。この大きさの表現として Guinier の慣性半径 ${ }^{19}$, Debye の相関距離 ${ }^{20}$, Ornstein-Zernike の相 関距離 ${ }^{21}$ などがある。Guinier の慣性半径と Debye の相関距 離は, 比較的大きさのそろった部分構造が生成している場 合，その空間的大きさの見積もりに適している。一方， Ornstein-Zernike の相関距離は, 様々な大きさの部分構造が 混じり合い特徵的な大きさの無い系, 例えば超臨界流体で の臨界点近傍や相分離する溶液での分離点近傍等への適用 が適しているようである。

\section{6. 解析例}

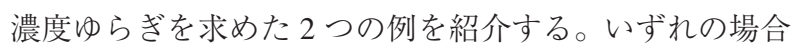
も, 3 種の物理量を実験で求める必要がある。X 線小角散乱 実験より， $s \rightarrow 0$ とした X 線散乱強度 $I(0)$ を求める。注目 している濃度近傍で, 濃度を細かく変えて試料の密度測定 を行い，2つの成分のそれぞれの部分モル体積 $\left(v_{\mathrm{A}}, v_{\mathrm{B}}\right)$ を 求める。圧力を変えた密度測定を行うことにより, 注目濃 度での等温圧縮率 $\kappa_{T}$ を求める。これらの測定值を(14) 式に 代入することにより，濃度ゆらぎが求まる。

最初の例は，アセトニトリル $(\mathrm{AN})$-水系である ${ }^{22}$ 。 $\mathrm{AN}$ は，小さな疎水基のメチル基と極性基のシアノ基から成る。 前述したように $c=0.38$ (c：ANのモル分率), $272 \mathrm{~K}$ で上 部臨界点を有する相分離する系である。メチルアルコール は水とほぼ理想的に混ざり合う。いずれも極性基であるに も関わらず， $\mathrm{OH}$ 基と $\mathrm{CN}$ 基だけの違いで，このように両極 端の挙動を呈することは興味深い。温度や濃度に応じて, どのように，ミクロスケールの混ざり方の不均一さがマク
ロスケールの相分離に至るかを調べるために，温度を 273 K, $279 \mathrm{~K}, 298 \mathrm{~K}$ として様々な濃度でゆらぎを求めた。 Figure 2(a)，（b)，（c)に，濃度ゆらぎ，密度ゆらぎ，2つの ゆらぎの相関を示す。すべてのゆらぎの濃度依存性カーブ は, $c \approx 0.38$ で極值を示している。すなわち, この濃度が, 温度に関係なく混合状態の最も不均一な状態と結論される。 また, 臨界温度 $272 \mathrm{~K}$ に近づくにつれ急激にその絶対值は 大きくなる。横軸を $c$, 縦軸を $T$ とした相図上に濃度ゆら ぎの等高線を描いたものが, Figure 3 である。図中での○印 は測定点である。数值は濃度ゆらぎの值を示し, 破線はそ れぞれの等高線である。臨界点に近づくにつれ，急激に濃 度ゆらぎが大きくなっていることがわかる。直線 $\mathbf{a}$ は, 後 に示す $\mathrm{AN}$ 分子のみの密度ゆらぎの極值を連ねたものであ
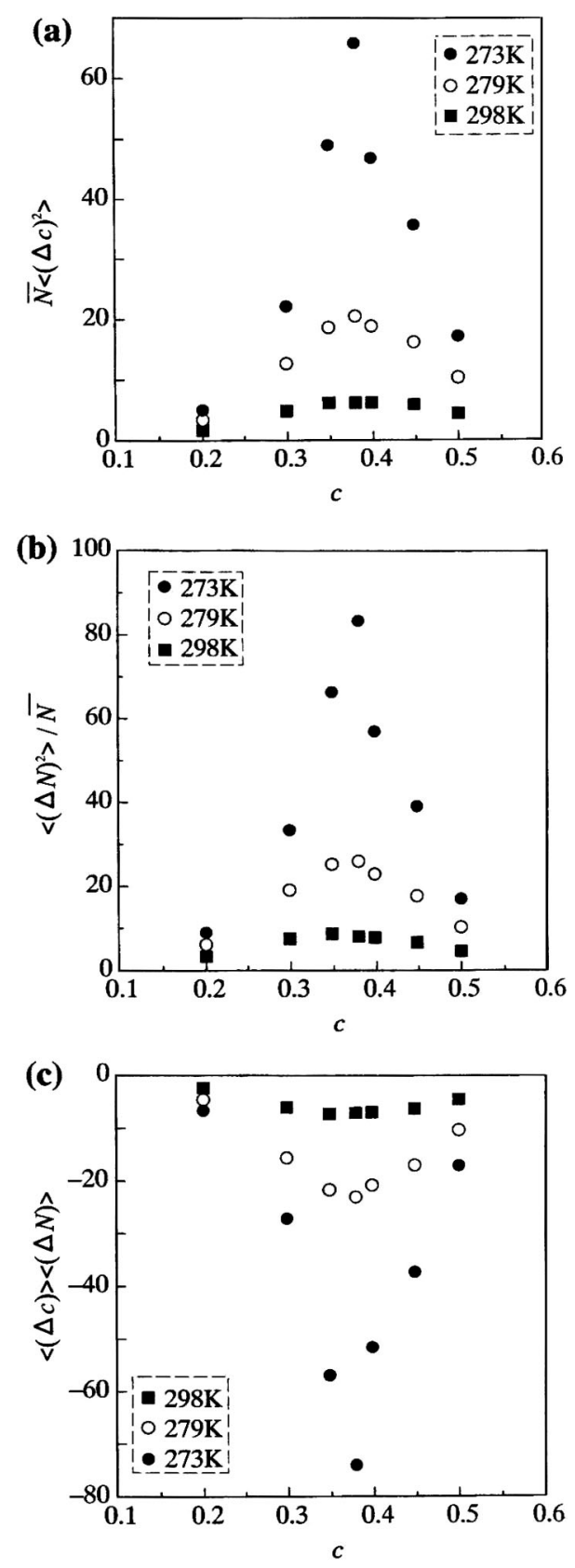

Figure 2. Fluctuations of aqueous acetonitrile solutions. (a) Concentration fluctuation, (b) density fluctuation, and (c) cross term. 


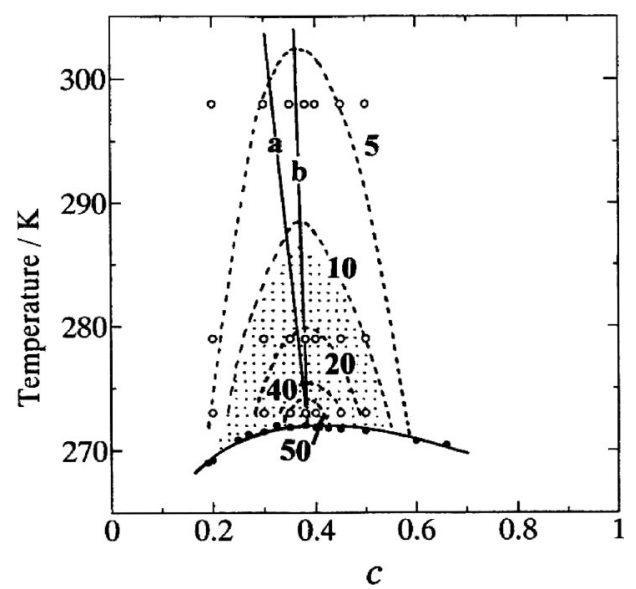

Figure 3. Contour curves (broken curves) of the concentration fluctuation of aqueous acetonitrile solutions. The numbers on the curves show the values of the concentration fluctuations. Solid curve refers to the miscibility curve. Open circles are the measured points. The dotted area shows the Ornstein-Zernike region.

り, 直線 $\mathbf{b}$ は水分子のみの密度ゆらぎの極值の軌跡である。 系全体の濃度ゆらぎの極值の軌跡と水分子のみの密度ゆら ぎの極值の軌跡はほぼ一致しており, 水分子の不均一分布 の影響がゆらぎ全体に，より強い影響を及ぼしていると言 える。ドットで示した領域は, Ornstein-Zernike 的描像の領 域（比較的大きさのそろったクラスターが分布するのでは なく，様々な大きさのクラスターが入り交じった領域）と 判断される。

(23)式より, AN 分子のみの密度ゆらぎ, および水分子の みの密度ゆらぎが求まる。模式的に混合状態を示した Figure 1 (b)，(c)において，黄色の粒子のみを見ているか, 青色の 粒子のみを見ているかに相当する。結果を Figure 4(a)，（b） に示す。これに対して, Figure 2(b) は, AN か水かを区別し ない密度ゆらぎである。臨界点近傍で急激に分子分布のゆ らぎは大きくなっている。 AN と水を比較してみると, 密度 ゆらぎの值は水のほうが 5 倍ほど大きく, 水の空間的不均 一分布が系全体のゆらぎを，より強く支配していることが わかる。

第 2 の例は，超臨界状態にある $n$-pentane $(n \mathrm{P}$ と省略 $)-$ 水の例である 23 。『水と油』という言葉があるように，通常 の状態では，水と典型的な有機物は混ざり合わない。しか し, 水を亜臨界や超臨界状態にすると, 有機物とよく混じ り合うようになり，逆に無機物を溶かさなくなる。有機物 とどのように混じり合うのかについての知見を得るために， $n \mathrm{P}$-水のゆらぎ解明の実験をスタートさせた。手始めに行っ た $n \mathrm{P}$ のモル分率にして 0.088 の濃度で, 水の臨界温度に 沿った等温実験の結果を紹介する。

Figure 5 は, 現在明らかになっている $n \mathrm{P}-$ 水系の相図と, 紹介する実験の測定点 $(\mathbf{a} \sim \mathbf{f})$ である。 $\mathrm{CP}_{\mathrm{C}_{5} \mathrm{H}_{12}}$ および $\mathrm{CP}_{\mathrm{H}_{2} \mathrm{O}}$ は, それぞれ $n \mathrm{P}$ と水の臨界点を示す。 $\mathbf{a} \sim \mathbf{f}$ の状態は, 目視により 1 相であることを確認している。ゆらぎの測定 結果を Figure 6 に, 密度ゆらぎ (赤色の丸), 濃度ゆらぎ
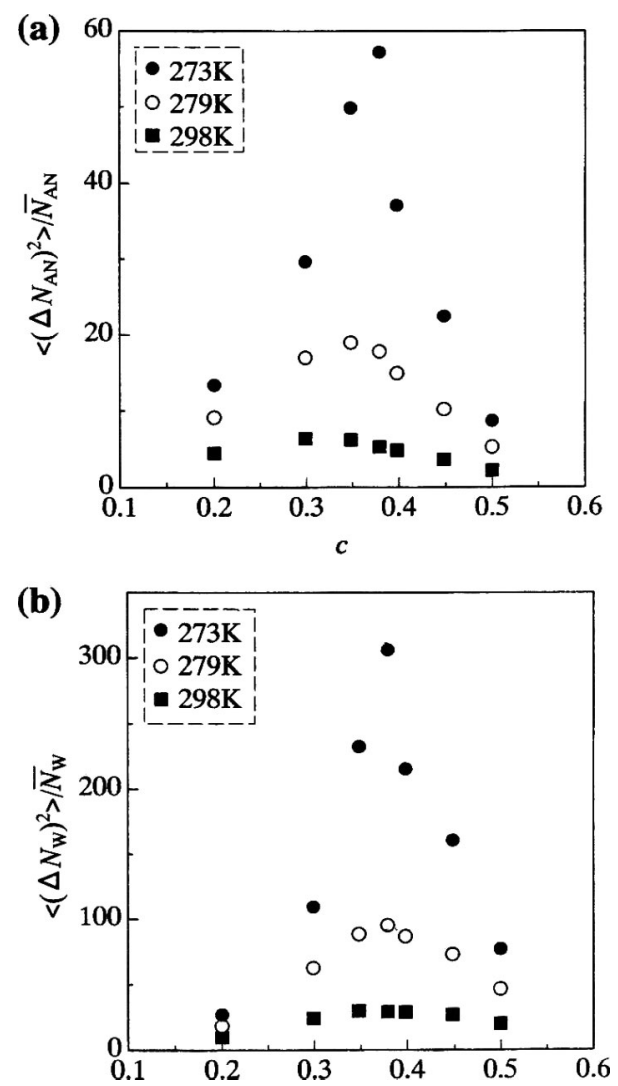

Figure 4. Particle number fluctuations of (a) acetonitrile and (b) water for aqueous acetonitrile solutions.

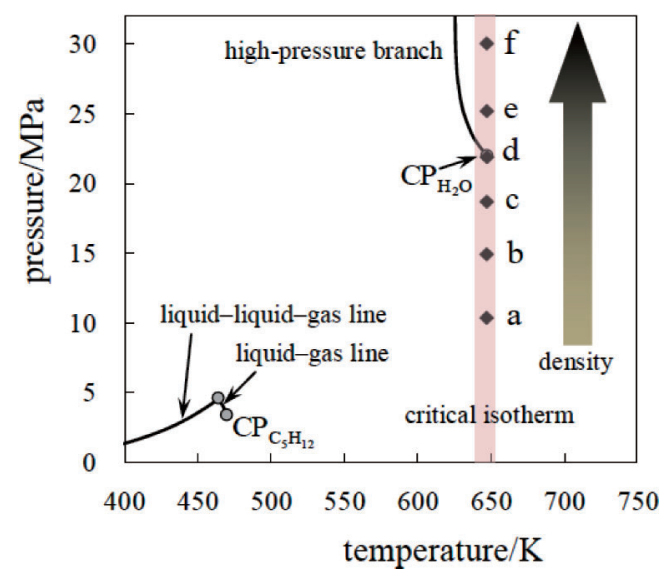

Figure 5. Measurement points on phase diagram of $n$-pentane-water system. CP represents the critical point for each one component of $n$ pentane $\left(\mathrm{C}_{5} \mathrm{H}_{12}\right)$ and water $\left(\mathrm{H}_{2} \mathrm{O}\right)$. UCEP denotes the upper critical end point.

(青色のダイアモンド)，2つのゆらぎの相関（緑色の四角） としてプロットした。密度ゆらぎや濃度ゆらぎの極大值は, おそらく $\mathbf{e}$ 点と $\mathbf{f}$ 点の間にあると思われる。(23) 式から水 および $n \mathrm{P}$ それぞれの密度ゆらぎを算出した結果を Figure 7 に示す。 $\mathrm{AN}$-水系と同様に, 水分子の不均一分布がはるか

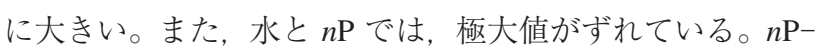
水系でも, 水の不均一分布が系全体のゆらぎ構造を支配す る,より強い因子である。

超臨界状態では, 温度・圧力・濃度の 3 つのパラメータ を変える必要がある。また, 水の超臨界状態は高温・高圧 


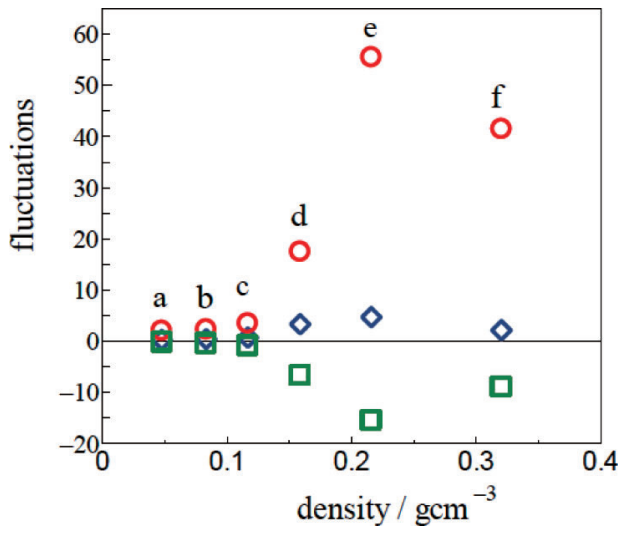

Figure 6. Fluctuations in density (red circle), concentration (blue diamond) and cross-term (green square) for $n$-pentane-water mixture at $647 \mathrm{~K}$ as a function of density of the mixtures. The mole fraction of $n$ pentane is 0.088 .

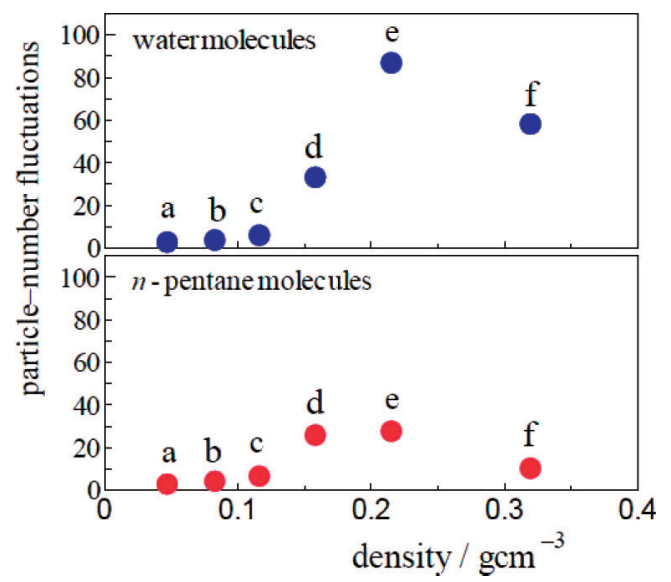

Figure 7. Particle-number fluctuations of each component of supercritical $n$-pentane-water mixture as a function of density of the mixture along the critical isotherm of water.

であり（水の臨界温度：647.3 K, 臨界圧力： $22.12 \mathrm{MPa）}$ 実験が難しいこと等の理由で，まだ多くの状態でデータを 収集していないが，ゆらぎの観点から，構造を見ていくと 新しい知見が得られると思われる。

物質科学でゆらぎが顕在化する現象の一例として溶液の 混ざり具合を取り上げた。このように，従来には無い観点 から構造と物性を観測・解析することによって，新たな物 質観を提案できると思っている。ゆらぎは『乱れ』とも言 い換えることが出来る。我々は，乱れを乱れとしてあるが ままに認識する重要性を指摘し, 静的な乱れの程度を定量 化する実験方法を確立した。この手法を多くの系に適用し， 乱れから生じる物性と機能を関連づけることも可能であ る 24,25 。

以上, 紹介したのは静的な構造であった。今, $\mathrm{X}$ 線光源 としてX 線自由電子レーザー（X-ray Free Electron Laser, XFEL）が話題を集めている。可視光や紫外線領域のレー
ザー分光が分子のダイナミクスを明らかにし，レーザー分 光学という大きな分野を生んだように, X 線を光源とした 分野でも, 従来の静的な情報に加えて, 動的挙動の研究が 飛躍的に展開すると思われる。

\section{引用文献}

(1) Nishikawa, K.; Iijima, T. Bull. Chem. Soc. Jpn. 1984, 57, $1750-1759$

（2）森田剛，田中良忠，西川恵子，放射光学会誌 2006，19, 402-407.

（3）例えば, 戸田盛和，松田博嗣，樋渡保秋，和達三樹，液体 の構造と性質；岩波書店：東京, 1976.

(4) Kirkwood, J. K.; Buff, F. P. J. Chem. Phys. 1951, 19, 774-777.

(5) Ben-Naim, A. J. Chem. Phys. 1977, 67, 4884-4890.

(6) Nishikawa, K. Chem. Phys. Lett. 1986, 132, 50-54.

(7) Bhatia, A. B.; Thornton, D. E. Phys. Rev. B 1970, 2, 3004-3012.

(8) Hove, L. V. Phys. Rev. 1954, 95, 247-262.

(9) Hayashi, H.; Nishikawa, K.; Iijima, T. J. Appl. Cryst. 1990, 23, 134-135.

(10) Waseda, Y. In The Structure of Non-Crystalline Materials; McGraw Hill: New York, 1980.

(11) Hu, J.; Haynes, C. A.; Wu, A. H. Y.; Chen, M. M.; Yee, E. G. M.; Ichioka, T.; Nishikawa, K.; Wesch, P.; Koga, Y. Can. J. Chem. 2003, 81, 150-155.

(12) Matteoli, E.; Lepoli, L. J. Chem. Phys. 1984, 80, 2856-2863.

(13) Lepori, L.; Matteoli, E. J. Phys. Chem. 1988, 92, 6997-7001.

（14）西川恵子，森田剛，第 5 版 実験化学講座 11 回折， 7.5 節； 丸善出版 : 東京, 2006 .

(15) Iwasaki, K.; Tanaka, M.; Fujiyama, T. Bull. Chem. Soc. Jpn. 1976, 49, 2719-2723.

(16) Iwasaki, K.; Fujiyama, T. J. Phys. Chem. 1977, 81, 1908-1912.

(17) Nishikawa, K.; Hayashi, H.; Iijima, T. J. Phys. Chem. 1989, 93, 6559-6565.

(18) Nishikawa, K.; Iijima, T. J. Phys. Chem. 1993, 97, 1082410828.

(19) Guinier, A.; Fournet, G. In Small-Angle Scattering of X-rays; Wiley: New York, 1955.

(20) Debye, P. J. Chem. Phys. 1959, 31, 680-687.

(21) Ziman, J. M. In Models of Disorder; Cambridge University Press: Cambridge, 1979.

(22) Nishikawa, K.; Kasahara, Y.; Ichioka, T. J. Phys. Chem. B 2002, 106, 693-700.

(23) Morita, T.; Murai, H.; Kase, S.; Nishikawa, K. Chem. Phys. Lett. 2012, (accepted).

（24）新井（鮎澤）亜沙子, 西川恵子, Photon Factory News Vol. 22, No. 2, 24-29, 2004.

（25）新井（鮎澤）亜沙子, 森田剛, 西川恵子, 高温高圧流体技 術研究会 Letter Vol. 19, 1-11, 2005.

（受理日 2012 年 4 月 27 日） 


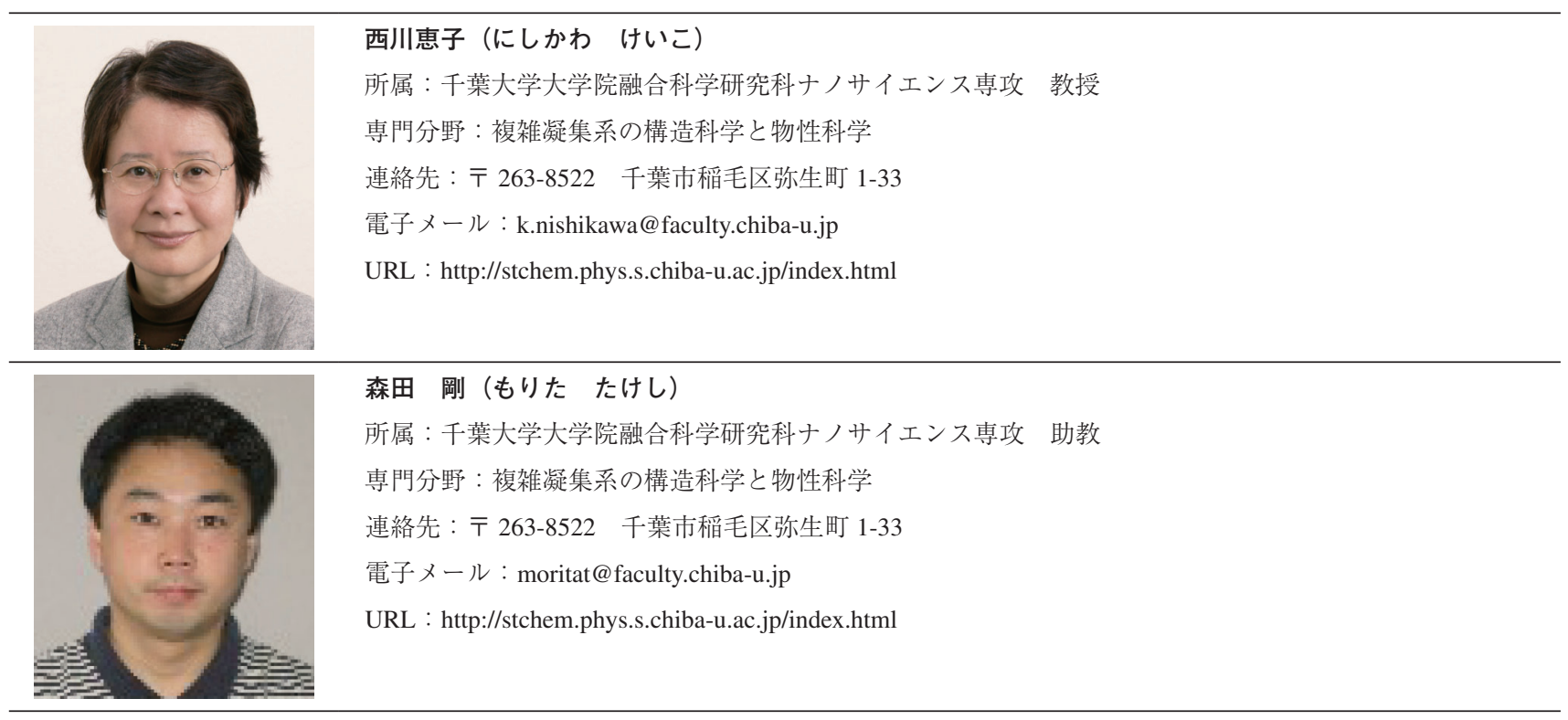

